\title{
Jazyk a krajina v antropologickém výzkumu Přemysl Mácha
}

DOI: 10.21104/CL.2021.4.01

Language and Landscape in Anthropological Research

\begin{abstract}
Language is a key element in the perception, formation, and reproduction of landscapes and group boundaries. It is effective in at least three dimensions, namely, the inner/cognitive, the outward/appropriative, and the collective/identitarian. The inner dimension refers to the fact that our perception of landscape and our spatial cognition are determined, to a large extent, by the linguistic terms and grammatical structures specific to our language. The outward dimension refers to the capacity of language to project linguistically- and culturally-determined understandings into the physical world and create and appropriate places and landscapes by the act of naming. Finally, the collective dimension points to the importance of the linguistic delimitation of landscapes and their association with group identities. The article summarizes crucial recent findings in all three of the aforementioned dimensions and suggests possibilities for further research.
\end{abstract}

\section{Key words}

language, landscape, place, linguistic relativity, identity, linguistic landscape

\section{Acknowledgment}

Text vznikl s podporou na dlouhodobý koncepční rozvoj Etnologického ústavu AV ČR (RVO: 68378076).

\section{Contact}

PhDr. Přemysl Mácha, Ph.D., Etnologický ústav AV ČR, v. v. i., Veveří 97, 60200 Brno, Czech Republic; e-mail: macha@eu.cas.cz.

ORCID iD: 0000-0001-9985-1064

\section{Jak citovat / How to cite}

Mácha, Přemysl. 2021. Jazyk a krajina v antropologickém výzkumu. Český lid 108: 403-430. https://doi.org/10.21104/CL.2021.4.01 
Jazyk je jedním z klíčových témat antropologie od jejího počátku jako vědecké disciplíny. Prochází např́č prakticky všemi lidskými činnostmi od interpersonální komunikace přes organizaci společnosti po symbolické vyjádření našich obav a tužeb. Podle některých autorů byl jazyk to, co nás odlišilo od ostatních organismů a co nás dělá lidmi (Friederici 2017). Tuto myšlenku ostatně rozvíjel již René Descartes (1992: 41). Zároveň není možné antropologii praktikovat bez dorozumění se s lidmi, které zkoumáme, a také jinými antropology, respektive širokou veřejností. Jazyk tedy stojí nejen na počátku a konci lidské kultury, ale také na počátku i konci antropologického bádání (Clifford - Marcus 1986; Van Maanen 2011). Není tedy divu, že jazyk se stal tématem natolik významným a specifickým, že dal dokonce vzniknout samostatné subdisciplíně - lingvistické antropologii.

Tento článek se však nevěnuje jazyku jako takovému, ale pouze jednomu jeho dílčímu, nicméně velmi důležitému aspektu, a tím je jeho role ve vnímání a utváření krajiny. V posledních desetiletích se do popředí antropologických studií krajiny dostávají fenomenologické a post-fenomenologické přístupy, které zdůrazňují tělesnou a žitou interakci člověka s prostředím, respektive vzájemné ko-konstituování lidských a mimolidských, živých i neživých aktérů (např. Tilley 1994; Ingold 2000; v českém prostředí např. Gibas - Pauknerová 2009; Kapusta 2015; Pauknerová 2019). Výzkumy založené na jazyku, textu a diskurzu upadly v nemilost jako př́liš limitující v pochopení plného rozsahu našeho vztahování se ke světu. Do značné míry je tato kritika samozřejmě oprávněná, protože mnoho našich každodenních aktivit provádíme a zažíváme bez potřeby jazykového vyjádření či uchopení - prostě jsme. Př́liš̌ný důraz na mimojazykové způsoby interakce se světem a jeho multiplicitou aktérů je ale nutně parciální podobně jako dř́ivější př́lišný důraz na jazyk a text. A nejen to, takový př́stup je také pokrytecký. V antropologii totiž vše začíná a končím jazykem - od nadefinování teoreticky ukotvené výzkumné otázky a formulace výzkumného záměru vztaženého k dřivějším výzkumům přes př́pravu grantové žádosti a provedení terénního šetření shrnutého do spousty poznámek, deníků a záznamů až po vyúčtování grantu a odevzdání článku do recenzního řízení. Toto zdaleka není banální konstatování. Bez jazyka by nebylo antropologie ani antropologů. A jelikož si nelze představit antropologické studium krajiny bez jazyka, bylo by pošetilé se domnívat, že lze roli jazyka v percepci a utváření krajiny pominout. Už jen proto, že prostorové kategorie a reflexe prostorových zkušeností, kterými se výzkumně zabýváme, nejsou ani samozřejmé ani přirozené. Kritická reflexe jazyka ve studiu krajiny je tedy rovněž na místě.

V tomto článku představuji vybrané antropologické př́spěvky k porozumění vztahu jazyka a krajiny. Tyto příspěvky člením do třech základních tematických okruhů či aspektů: vnitřního či kognitivního, vnějšího či 
propriálního a skupinového či identitárního. V prvním shrnuji nejnovější poznatky o vlivu jazyka na percepci prostoru. Takzvaný jazykový relativismus vyvolal v antropologii mnoho polemik, nejnovější výzkumy ale naznačují, že ignorovat vztah jazyka a prostorové percepce by bylo značně nerozumné. V druhém okruhu se zaměřuji na práce, které zkoumají a promýšlejí vliv jazyka na utváření krajiny. Z řady studií se ukazuje, že jazyk má krajinotvorný potenciál. Vnější projevy jazyka (nap̌r. v podobě zeměpisných jmen) utvářejí ráz krajiny stejně tak jako (a někdy dokonce i více než) její geomorfologie a vegetační pokryv. V posledním okruhu se věnuji vztahu jazyka, krajiny a identity, tj. jakou roli hraje jazyk v utváření a reprodukci skupinových hranic v prostoru. Je to samozřejmě jen hrubé rozlišení, které naráží na skutečnost, že v běžném životě jsou všechny tyto tři aspekty jazyka úzce provázané. Domnívám se ale, že toto členění je ospravedlnitelné s ohledem na důraz, který tomu či onomu tématu jednotliví antropologové přikládají. Na závěr nastiňuji některé meze těchto př́stupů a možné směry, kterými by se bádání o vztahu jazyka a krajiny mohlo dále ubírat.

Než přejdu k vlastnímu tématu, musím zdůraznit, že ve vztahu jazyka a krajiny se v tomto textu zabývám pouze jazykem a jeho různými projevy, nikoliv krajinou. Koncept krajiny je velmi komplexní a kontroverzní a vyšla $\mathrm{k}$ němu celá řada podnětných a provokativních prací (viz např. Tilley 1994; Hirsch - O'Hanlon 1995; Olwig 1996; Cosgrove 1998; Ingold 2000; Wylie 2005). Chápání krajiny má samozřejmě dopad na to, jak uvažujeme o roli jazyka v její percepci a jejím utváření. S ohledem na rozsah textu však není možné rozpracovat koncept krajiny ve stejné míře, v jaké se zabývám jazykem. Jakkoliv se jedná o nutné zjednodušení, pojmem krajina proto v tomto textu budu myslet především tu výseč prostředí, které určité společenství vnímá jako relevantní rámec svého bytí a konání (blíže viz Mácha 2010).

\section{Jazyk a percepce krajiny}

Zájem o vztah jazyka a kultury je téměř stejně starý jako antropologie samotná a pojí se se zakládajícími osobnostmi disciplíny (Duranti et al. 2003). Jedním z prvních průkopníků antropologického zájmu o jazyk byl již Franz Boas, který spolu se svými studenty položil základy lingvistické antropologii. Osvojení si jazyka studovaných společností byla praktická nutnost, zároveň se ale rychle ukázalo, že jazyk je oknem do myšlení, které se v mnohém radikálně liší od evropských představ o „skutečném“ uspořádání světa. $\mathrm{V}$ tomto duchu se postupně rozvíjela folktaxonomie, etnofarmakologie, etnobotanika, etnozoologie či obecněji etnověda jako pokus o porozumění kategoriím a klasifikačním schématům jednotlivých společenství (Sturtevant 1964). 
Z pohledu tohoto článku je obzvláště důležitá etnogeografie, která brzy následovala prvotní zájem o jazyk a přinesla řadu kvalitních etnografických studií geografických klasifikačních systémů konkrétních společností (viz např. Harrington 1916). Předmětem zájmu etnogeografie jsou „místa, která určité společenství rozlišuje ve svém okolí, klíčové lokality, které dávaji tomuto společenství hodnotu a smysl“ (McCarthy 1986: 24) či obecněji soubor „„v̌ech geografických predstav členů určité lidské skupiny v určitém čase" (Blaut 1979: 2). Vzhledem k širokému významu a nejednotnému užívání termínu etnogeografie někteří autoři preferují pojem etnofyziografie (např. Mark - Turk - Stea 2010) jako etnovědu krajiny, tj. výstižnější vyjádření zájmu o geografické kategorie užívané různými skupinami pro popis krajiny, jejích konstitutivních prvků a procesů, které v ní probíhají. Ještě jiní upřednostňují obecnější termín krajinná etnoekologie, zahrnující vedle fyzických struktur a procesů také živé součásti prostředí - rostliny, živočichy a další bytosti (viz např. Johnson - Hunn 2010b). Koneckonců právě s tímto př́stupem se pojí jedny z nejvlivnějších antropologických prací nedávné minulosti (Descola 1994; Viveiros de Castro 1998; Descola 2013).

At' už tento př́stup nazveme etnogeografí́, etnofyziografií či krajinnou etnoekologií, v pozadí zájmu stojí dva základní okruhy otázek. Za prvé, liší se identifikace, rozlišení a klasifikace krajin a krajinných prvků v čase a mezi různými skupinami? Existují univerzální prostorové či krajinné kategorie? Vidí všichni lidé stejné prvky v dané krajině, respektive vidí stejné krajiny? Pokud ne, čím pozorované rozdíly v percepci a klasifikaci krajiny můžeme vysvětlit? A za druhé, jakou roli v těchto rozdílech sehrává jazyk? Slouží jazyk jako pouhé vyjádření kulturně-specifických klasifikačních schémat, nebo je naopak svou lexikální a gramatickou strukturou předurčuje? Obě otázky jsou velmi důležité z hlediska komparativního studia krajiny a role jazyka v její percepci, organizaci a popisu.

Jak upozorňují Burenhult a Levinson (2008), povrch Země je kontinuum, netvoří jej předem dané a od sebe jasně oddělené objekty. Mluvčí různých jazyků toto kontinuum na základě různých kritérií (tvar, velikost, materiál, funkce aj.) člení na dílčí části, jakési kvaziobjekty (např. hora, kopec, údolí, úval, potok, říčka atd.), s nimiž následně zacházejí - jazykově i behaviorálně - jako se skutečnými objekty. Z komparativních studií se ale ukazuje, že to mluvčí různých jazyků dělají různě a že jen obtížně budeme hledat univerzální krajinný prvek rozlišovaný stejně ve všech jazycích. A co víc, dokonce to nedělají stejně ani mluvčí totožných či blízce př́buzných jazyků.

Např́klad mořský led hraje v krajinné percepci Inuitů obecně velmi významnou roli a inuitské jazyky mají mnoho termínů pro různé druhy mořského ledu (Aporta 2010). Není tomu tak ale v jižním Grónsku, pravděpodobně proto, že se tam mořský led prakticky nevyskytuje. Tamní Inuité 
rozlišují především geomorfologické prvky svázané s pevninou a vodou (vegetace vzhledem k jejímu minimálnímu zastoupení a pokrytí sněhem po velkou část roku v krajinné percepci a terminologii nehraje prakticky žádnou roli). K vodě patří i pobřežní prvky (např. fjordy či ostrovy), zatímco na pevnině se primárně rozlišují konvexní prvky od všech ostatních (Grenoble - McMahan - Kleist Petrussen 2019: 10-11). Primárním konvexním termínem je qaqqaq, což lze volně přeložit jako skalnatá vyvýšenina konického tvaru libovolné velikosti („kopec“, „hora“). Zarovnaná skalnatá vyvýšenina se označuje jako qaarsoq, přičemž může tvořit část qaqqaq. Pokud je vyvýšenina jiného než skalnatého původu (třeba hliněného), označuje se jako pingu. Místní inuitština tedy rozlišuje vyvýšeniny nikoliv podle velikosti, ale podle tvaru a materiálu. Podobně jako inuitština nerozlišují vyvýšeniny konického tvaru podle velikosti ani mayský jazyk tzeltalština (Brown 2008) či melanéský jazyk Yélî Dnye (Levinson 2008). Mají pro ně jen jeden termín - witz, respektive mbu. V australském jazyce jindžinbarndištině (Yindjinbarndi) se sice rozlišují konvexní tvary reliéfu podle velikosti, ale práh rozlišení je výrazně níže než třeba v češtině - marnda se používá pro hory, pohoří a většinu kopců, zatímco bargu jen pro nejmenší vyvýšeniny. Marnda ale znamená také peníze, skálu, kov či rudu, tedy tvrdé materiály (Mark - Turk - Stea 2010: 38). V polynéském jazyku markézštině se vyvýšeniny naopak rozlišují podle tvaru a umístění - tuaivi je hora tvořící stranu údolí, mouka je samostatně stojící hora a ivi je hora, která je součástí horského hřebene (Cablitz 2008: 206). V této souvislosti stojí rovněž za připomenutí dnes již málo užívané či zcela zapomenuté české termíny pro konvexní tvary reliéfu jako napŕíklad baba, chřib a brdo nebo termíny specifické pro části Česka ovlivněné takzvanou valašskou kolonizací jako například kyčera, gigula, grúñ čupel, beskyd a příschlop. Přeložit tyto termíny do současné češtiny, natož do tzeltalštiny či markézštiny, by asi byl opravdu ořišek. Za horskou exotikou tedy rozhodně nemusíme daleko, pokud ovšem hory vůbec existují (viz Smith - Mark 2003).

Kromě jednotlivých krajinných prvků, které slouží jako opěrné body prostorové kognice, jsou podobně pestré také referenční rámce, kterými jednotlivé jazyky uspořádávají krajinné prvky do složitějších celků a které využívají pro lokalizaci objektů v krajině. Ve stručnosti lze rozlišit tři základní rámce - absolutní, relativní a objektu vlastní (intrinsické). Záleží na tom, zda je lokalizace nezávislá na mluvčím, respektive objektu, který lokalizujeme. Absolutní referenční rámce používají abstraktní koordinační systém (např. sever/jih), relativní referenční rámce se opírají o proměnné koordinační systémy závislé na úhlu pohledu (např. vlevo/vpravo) a referenční rámce vlastní objektu odvozují polohu od vnímaných vlastností objektu (např. „, přední části autobusu“). Jiným způsobem bychom mohli 
rovněž rozlišit egocentrické a alocentrické referenční rámce. Podstatné je, že některé jazyky využívají jen jeden z těchto rámců, jiné je systematicky kombinují, ale žádný z nich není univerzálně rozšířený (Levinson 1996). Pro jazyky, jimiž hovoří lovecko-sběračské skupiny, jsou např́íklad charakteristické absolutní referenční rámce (O’Meara et al. 2020).

Podobně jako u jednotlivých krajinných prvků nacházíme různorodost i na úrovni celé krajiny. Již termíny pro krajinu v evropských jazycích (např. krajina, landscape, paysage) naznačují etymologickou a konceptuální odlišnost. České slovo krajina je etymologicky př́buzné se slovy $k r a j$, okraj, vykrojit, ale zprostředkovaně také kroj. Ve všech případech odkazuje na lidskou aktivitu, „ukrajování“ nějaké části našeho prostředí (viz např. Holub - Lyer 1967: 266-268). Poučné je rovněž nahlédnutí do druhého svazku Jungmannova Slownjku česko-nèmeckého (1836: 160-161), kde pod heslem krajina nalezneme velice pestrý výčet významů a př́kladů z literatury, které s dnešním významem slova nemají v naprosté většině případů nic společného. Převládající význam v Jungmannově době, zdá se, byl „stát“ či „zeměc v politicko-teritoriálním smyslu, popř́padě území na okraji státu. Právě na právní a politickou rovinu utváření krajiny upozornil např́́klad Olwig (1996), který polemizoval s pojetím krajiny jako vizuální ideologií (viz níže) a upozorňoval na materiální základy utváření krajiny. Anglická etymologie slova landscape (Jackson 1984: 5-8) rovněž odkazuje na aktivní prvek vyčleňování části prostředí a v moderním úzu dokonce i tvarování prostředí (sloveso to landscape). Etymologie slova krajina v románských jazycích (paisaje, paysage, paesaggio apod.) je odlišná, ale i ji je dobré vzít při úvahách o významu krajiny v potaz. Na počátku totiž stálo slovo pagus (rurální distrikt) a krajina v románských jazycích tedy původně označovala venkov (Jackson 1984: 5).

Nemělo by tedy být úplně překvapující, že tyto etymologické a konceptuální rozdíly ovlivňují vnímání krajiny v rámci samotné Evropy. Ačkoliv všechny evropské jazyky termín pro krajinu mají, jsou v dlouhodobém vzájemném jazykovém a kulturním kontaktu a hovoří se jimi v geomorfologicky a ekologicky relativně podobných prostředích, popisy krajiny a jejích konstitutivních prvků jejich mluvčími se výrazně liší, a to jak systematicky (románské vs. germánské jazyky), tak individuálně (Van Putten et al. 2020). Nejen jednotlivé krajinné prvky, ale ani krajinu jako celek proto rozhodně nelze považovat za univerzálie. ${ }^{1}$

Jen některé jazyky ale mají termín pro krajinu jako celek, jiné často ani nerozlišují krajinu od dalších jazykových domén (tělo, př́ibuzen-

1 Pro zájemce o bližší seznámení s rozmanitostí krajinné percepce a jazykových kategorií prostorové klasifikace na různých místech světa doporučuji např. Levinson (2003), Johnson a Hunn (2010a) nebo Mark et al. (2011). 
ství, hospodářství, náboženství aj.) (Burenhult - Levinson 2008: 143). Např́klad tzeltalština zcela postrádá termín pro krajinu a pro prostorovou orientaci používá termíny odvozené od částí těla (hlava, nos, rty, břicho apod.), jimiž se diferencují různé části reliéfu, respektive umístění různých objektů v terénu (Brown 2008). V jazyce sanské skupiny *Akhoe Hai//om žijící v Namíbii abstraktní termín pro krajinu rovněž neexistuje. Rozlišují ale „krajiny“ na základě charakteru území a skupiny, která ho obývá. Fyzická geografie a etnická struktura tak dávají vzniknout multiplicitě „krajin“, každá s vlastním jménem/termínem. Člověk a prŕrodní prostředí jsou v tomto jazyce nerozlučně kognitivně a lingvisticky spjaty (Widlok 2008).

Nemůžeme tedy vůbec předpokládat, že lidé všude na světě krajinu vidí, respektive že své prostředí vnímají jako jednoznačně uspořádaný, vymezený, či dokonce harmonický (lokální) celek. Koneckonců přesně na toto upozornil již před časem Cosgrove (1998: 1), který argumentoval, že krajina v evropském či euroamerickém pojetí je spíše historicky a socio-ekonomicky podmíněný způsob nazírání na svět, kterému se musíme naučit, nikoli něco samozřejmého či přirozeného, co existuje „tam venku“ a čeká na své objevení antropology a geografy.

Např́klad Janomamové v severní Brazílii nevnímají a nevyužívají krajinu koncentricky v závislosti na vzdálenosti od vesnice, tj. jako jakousi obálku jejich sídel. V př́padě Janomamů krajina rozhodně není to, kvůli čemu lezeme na rozhlednu, jak ř́ká biolog Jiří Sádlo. Janomamskou krajinu tvoří uzly a linie utkané do sítí, které jsou interpretované ze země. Percepci a využívání krajiny ovlivňuje její prostupnost pomocí stezek a vodních toků. To má mimo jiné i velmi reálné dopady z hlediska rozlohy území, které je Janomamy skutečně využíváno. Oproti standardnímu odhadu založenému na vzdálenosti je odhad sítový poloviční, protože mezi liniemi a uzly zůstává mnoho „prázdného" prostoru, který není součástí janomamské krajiny (Albert - Le Tourneau 2007). V této souvislosti si nelze nevzpomenout na Ingoldovu koncepci krajiny jako textilie či sítoviny (meshwork) utkané z linií jednotlivých životů (Ingold 2011).

Ve většině př́padů se krajinou nekocháme, ale stejně jako Janomamové se v/s ní pohybujeme a pracujeme. Pohyb, jak upozornil Ingold (ibid.), utváŕí krajinu a nacházení a čtení cesty je jednou z klíčových schopností člověka. Orientace v krajině však nemusí vycházet $\mathrm{z}$ prvků v našem bezprostředním okolí, ale může být založena na horizontu, pohybu ledu a směru větru, jako tomu je např́íklad mezi Inuity v severní Kanadě. Směr větru rozděluje horizont na šestnáct dílů a slouží jako větrný kompas (Aporta 2010). Podobné větrné, ale také hvězdné kompasy využívají námořníci v Polynésii jako klíčové prvky mořské krajiny (Goodenough - Thomas 1987). 
Zjevná rozmanitost ve vnímání krajinných prvků a krajiny ilustrovaná předcházejícími př́klady vede $\mathrm{k}$ otázce, co tuto rozmanitost způsobuje a jakou roli v této rozmanitosti hraje jazyk. Ačkoliv někteří autoři argumentují ve prospěch ekologického vysvětlení (jazykových) rozdílů v prostorové percepci adaptací na prŕrodní prostředí (např. Hansen - O’Meara 2020; Urban 2020), jiní jsou k tomuto vysvětlení spíše skeptičtí (viz Burenhult - Levinson 2008; Nash et al. 2020). Heegård a Liljegren (2018) např́klad ukázali, že i jazyky blízce prŕbuzné, kterými se mluví v totožných prostř̌edích, se $\mathrm{v}$ mnoha aspektech prostorové klasifikace a percepce mohou výrazně lišit.

Pokud jazyk krajinné terminologie není nutným výsledkem adaptace na prostředí, lze uvažovat, že vztah mezi prostorovou percepcí a jazykem je spíše opačný, tj. že jazyk ovlivňuje prostorovou percepci? Domnívá se tak stále více badatelů. V obecné rovině sice není vztah jazyka a myšlení jednoznačně vyřešen a problém jazykové relativity stále budí značné emoce (Lucy 1997; Sharifian 2017). V oblasti prostorové kognice se situace díky probíhajícím výzkumům ale poměrně vyjasňuje (Burenhult - Levinson 2008). Např́iklad Majid et al. (2004) ukázali, že referenční rámce nemají univerzální neurokognitivní základ, ale jsou determinovány jazykem. Podobně Haun et al. (2011) experimentálně ověřili, že jazyk sice nevytvář́ nepřekročitelné bariéry prostorové kognici, ale jednoznačně a významně ji usměrňuje. Změnit prostorovou kognici je pro mluvčího určitého jazyka sice možné, vyžaduje to však zvýšené úsilí a vede to $\mathrm{k}$ horším výsledkům při řešení prostorových úloh. Jazyk nás tedy ponouká uvažovat o prostoru či krajině určitým způsobem. Tato zjištění nás při studiu lidského prostorového chování nutí věnovat zvýšenou pozornost tomu, jak lidé prostor či krajinu kognitivně a lingvisticky uchopují a strukturují a jak jí rozumí. Jakkoliv se prostorová terminologie v důsledku formálního vzdělávání ukotveného v západní vědě napříč světem homogenizuje, lidová etnogeografie či etnoekologie vždy zůstane zásadním faktorem v prostorovém chování lokálních společenství.

\section{Jazyk a utváření krajiny}

Etnogeografie, etnofyziografie či krajinná etnoekologie se zaměřují na vnitřní či kognitivní rozměr vztahu jazyka a krajiny se zvláštním zřetelem k obecným lingvistickým a kognitivním kategoriím užívaným členy určitých společenství k perceptuální organizaci krajiny a zacházení s ní. Prioritou zájmu jsou zde tedy takzvaná apelativa, tj. slova s obecným významem typu údolí či řeka, respektive čím se liší kopec od hory. V reálném světě, snad jen s výjimkou profesionálních geografů, s těmito obecnými 
termíny ale moc často explicitně nepracujeme. Spíše se opíráme o aplikaci těchto apelativ v konkrétních krajinách, a to v podobě vlastních jmen, takzvaných proprii v obecném smyslu či toponym v užším geografickém smyslu. Nejdeme na horu ale na Lysou horu či jen na Lysou, a když jdeme $\mathrm{k}$ řece, nejdeme $\mathrm{k}$ nějaké obecné abstraktní řece, ale té naší Řece, tř̌eba Morávce. Pouze když se ocitneme v nám neznámé krajině, uchylujeme se dočasně k apelativům a zároveň se většinou pokoušíme zjistit od místních, kde to vlastně jsme a na co se to díváme. Jako bychom intuitivně cítili, že použití apelativ není ke krajině spravedlivé a že obecné krajiny neexistují. Jako bychom cítili, že krajina beze jmen vlastně ani opravdovou (lidskou) krajinou není. ${ }^{2}$

\begin{abstract}
Jak zdůrazňuje Tuan (1991: 685-688), „lidé obecně znají moc jazyka z běžné, každodenni zkušenosti. Védí, že ačkoliv jazyk sám nemůže materiálně zmènit př́rodu, může usmèrnit pozornost, uspořádat bezvýznamné entity do významuplných složitých celki̊, a tím tak učinit dř́ve prehlížené - a proto neviditelné a neexistující - věci viditelné a skutečné...Vlastní jméno a zemépisný objekt splývají v povědomí lidí, kteř̀ vèdí, že zmènit jméno znamená zmènit také objekt sám, jakkoli jemně a nevysvètlitelnè. Copak je po jméně? Co rữzi zvou, $i$ zváno jinak vonělo by stejnè. Ale ze zkušenosti většiny lidí toto jednoduše není pravda. Lidé berou jména vážně, at'už to jsou jejich vlastní, jména jiných lidí či jména zemépisných objektů. "
\end{abstract}

Přesně na tento intimní vztah mezi jmény, místy a krajinami poukazuje již delší dobu řada antropologů, geografů a dalších sociálních vědců. Průkopníkem tohoto zájmu mezi antropology byl zejména Basso (1988, 1996 aj.). Na rozdíl od dřiveješích toponymických studií v antropologii převážně soupisového charakteru (viz např. Harrington 1916; Harrington 1920; Laidler 1927; Boas 1934; Mirkovich 1941 atd.) však Basso nepřistupoval ke jménům jako k pouhým orientačním bodům v krajině ani jako k nástrojům pro rekonstrukci apelativní roviny krajinné terminologie v rámci etnovědeckých př́stupů. Basso pohlížel na jména jako na výpovědi lidí o sobě a světě kolem nich:

„Timmto zpưsobem [...] se etnograf dostává k pochopení místní krajiny tak, jak vyjádřeni predávaná v každodenní konverzaci nabývaji

2 Za zmínku v této souvislosti stojí nedávné přistání vozítka Perseverance na Marsu. Přistání proběhlo v kráteru Jezero. Pro mluvčího angličtiny nesrozumitelný jazykolam, pro mluvčího češtiny jednoznačná asociace a polidštění marsovské krajiny. 
hodnotu a význam prostřednictvím ideačních systémů, jimiž jsou chápány a vytváreny. Symbolicky konstituované, sociálně predávané a individuálnè používané, tyto systémy kladou meze na to, jak lidé mohou (a mají) poznávat fyzické prostředí, jak jeho obyvatelé mohou (a mají) jednat a jak činy obou mohou (a mají) být interpretovány jako vzájemně spojité." (1988: 100)

Studiem (žité) toponymie se tedy dle Bassa můžeme dozvědět mnoho o základních kulturních hodnotách, představách a významech, které pomáhají členům společenství v nalézání smyslu v chaotickém světě.

Ve své nejznámější práci Wisdom Sits in Places (1996) Basso jde ještě dál a poukazuje na existenciální a morální rozměr toponym. Za jednu ze základních činností člověka považuje place-making, tj. utváření míst kladením si otázek vztahujících se k historii a významu místa. Co se tady stalo? Kdo se toho účastnil? Jaké to bylo? Proč na tom vůbec záleží? Toponyma utvářejí místa, jsou to př́iběhy, dějiny vepsané a vpisované do prostoru. Náš svět je podle Bassoa světem složeným z míst, „místosvět", place-world. Svět je zažíván, chápán a zakoušen skrze místa, která mu dávají řád a smysl. Je srozumitelný, přehledný, intimní: „Znalost míst je [...] úzce spojena se znalostí sebe sama, se schopností chápat své místo ve svètèe, včetně svého společenství, a se získáním sebevědomé představy o tom, kým jsem jako člověk. " (Basso 1996: 34)

Bassovy práce ukazují, že jazyk v podobě zeměpisných jmen má na krajinnou percepci i krajinné chování výrazný vliv, a to bez ohledu na to, zda předpokládáme úzkou vazbu mezi vnitřní lexikální a gramatickou strukturou jazyka a kognicí (Reszegi 2020). Systematické studium toponym jako sociálních či symbolických a nikoliv lingvistických či kognitivních kategorií proto přináší celou řadu zajímavých otázek, jejichž řešení je zatím spíše v plenkách. Které krajinné prvky a místa jsou pojmenovány a které ne? Co činí určité místo natolik významné, že si zaslouží vlastní jméno, a jakou roli toto místo hraje v místním společenství? Jak se jednotlivá společenství liší v pojmenovávání krajinných prvků a míst a co tyto rozdíly vypovídají o mentálním nastavení a sociální organizaci těchto společenství? Jakými sociálními mechanismy se jména vytvářejí a sdílejí? Jak jména ovlivňují krajinnou percepci a krajinné chování? Jak se prostřednictvím jmen vytváří vlastnictví krajiny a představa krajiny jako domova? Jak se utvář́ představa sebe sama prostřednictvím zeměpisných jmen?

Jedním z klíčových rozměrů zeměpisných jmen, které jim udělují sociální relevanci, je jejich etymologie, respektive sociální význam. Je ale nutné rozlišovat mezi odbornou a lidovou etymologií (Burenhult - Levinson 2008). Obě jsou velmi významné, ale je tomu tak z odlišných důvodů. 
Odborná etymologie nám poodhaluje původní motivaci pro pojmenování a také gramatické a lexikální struktury a kategorie užívané mluvčími jazyka v době pojmenování. Je to nástroj k rekonstrukci apelativní roviny krajinné klasifikace, respektive krajinné etnoekologie. Lidová etymologie nám naopak ukazuje aktuální význam jména, respektive místa, s nímž se pojí. $\mathrm{Z}$ pohledu antropologa je proto často mnohem zajímavější než etymologie odborná. Se jménem se totiž pojí příběhy, vzpomínky, představy, očekávání a pocity a tyto následně ovlivňují, jak jméno a místo vnímáme a jak s ním zacházíme, přestože původnímu významu jména již často vůbec nerozumíme (Radding - Western 2010).

Bassovými pracemi se inspirovala řada dalších výzkumníků a dnes již disponujeme rostoucím počtem etnografických studií toponymické praxe různých společenství na mnoha místech světa (viz např. Cruikshank 1990; Hunn 1996; Thornton 1997; Jett 1997; O’Connor - Kroefges 2008; Meadows 2008; Levinson 2008; Kingston 2009; Koch - Hercus 2009; Boden 2011; Thornton 2011; Heikkilä 2014; Bigon 2016; Cogos et al. 2017). Z nich je zřejmé, že toponymické systémy, strategie a praxe se výrazně liší, a to v řadě aspektů. Některé jazyky jako např́klad apačština preferují čistě deskriptivní zeměpisná jména. Př́kladem mohou být jména jako T'iis Sikaadé (Topolový háj), Goshtt‘ish Tú Bit Sikqné (Voda s blátem v otevřené nádobě) či Gad 'O'ááhá (Jalovec stojí sám) (Basso 1996: 11-19). Rané kolonizátory deskriptivní charakter indiánských jmen často vedl k mylnému závěru, že indiáni vlastně žádná jména nemají (Bright 2003).

$\mathrm{Na}$ opačném konci spektra nacházíme honorifikační jména, to jsou jména vytvořená jako pocta osobám, místům či událostem bez jakéhokoliv přímého vztahu k pojmenovávanému místu či jeho charakteru (např. Pik Lenina, Mt. Everest, Stalingrad, Gottwaldov, Masarykovo nám., Revoluční ulice). ${ }^{3}$ Tato jména jsou charakteristická především (byt' ne výlučně) pro euro-americkou civilizaci a jsou úzce spjatá s politickými režimy a ideologiemi. Odhalují mocenský aspekt zeměpisných jmen jako nástrojů koloniální vlády a prosazení teritoriálních nároků (Cohen - Kliot 1992; Yeoh 1996; Nash 1999; Azaryahu - Golan 2001; Weber 2019) a legitimizace politických režimů (González Faraco - Murphy 1997; Alderman 2000; Light 2004; Gill 2005; Horsman 2006; Palonen 2008).

Většina z uvedených autorů jsou geografové, nikoliv antropologové, a ve svých pracích využívají často pouze kartografické a úřední prameny. Proto např́ílad Rose-Redwood, Alderman a Azaryahu (2010: 466) volali po větším využití etnografie jako klíčového nástroje ke studiu recepce

3 K využití honorifikačního motivu v českých zeměpisných jménech viz David (2011) a Křížová et al. (2017). 
a užívání toponym v každodenním životě. Př́íkladem takových etnograficky ukotvených studií interakce oficiální a každodenní žité toponymie jsou výzkumy Gonzáleze Faraca a Murphyho (1997) ve španělském městě Almonte či výzkumy Shovala (2013) v izraelském městě Acre, které odhalily paralelní toponymické systémy užívané různými skupinami ve stejné lokalitě. Právě tyto př́klady ukazují, že antropologie může výrazně přispět k systematickému pochopení role toponym v utváření místa, formování vztahu k domovu ale také v politice každodennosti.

Mezi těmito extrémy se nachází mnoho mezipoloh různě kombinujících deskriptivní, vlastnická, metaforická a honorifikační jména. Jazyky také různě využívají jména vztažená k objektům a jména vztažená k územím, respektive plochám. V některých jazycích se využívají pouze jména pro plochy, v jiných pouze pro objekty, což se následně odráží v krajinné percepci (Burenhult - Levinson 2008). V českém kontextu jsou např́klad specifická jména metaforického rázu odvozená od exonym - Mexiko, Argentina, Korea, Bosna, Balkán, Amerika či Balaton. Téměř v každém katastru alespoň jedno takové jméno nalezneme, často i více (viz Mácha - Krtička 2016). Co vypovídají tato jména o představách místních obyvatel o světu a zároveň, jak taková jména ovlivňují percepci „české“ krajiny?

Rose-Redwood (2008) dále ukázal, že pojmenovávání má nejen jazykový, ale také fyzický, performativní rozměr, který překlenuje falešnou dichotomii mezi jazykovým uchopením světa a jeho tělesným prožitkem. Nejviditelnějším vyjádřením materiální či performativní roviny jazyka je však takzvaná jazyková krajina (linguistic landscape), které je zatím $\mathrm{v}$ antropologii na rozdíl od jiných oborů věnovaná malá pozornost. V užším smyslu se jedná o toponymické i netoponymické texty ve veřejném prostoru - úřední cedule, billboardy, tabulky, plakáty, graffiti, transparenty, reklamní nápisy, památníky a podobně (Landy - Bourhis 1997: 25). V širším smyslu zahrnuje též kontextuální diskurzivní interpretaci a performativitu těchto textů (Scollon - Scollon 2003), etnografii textové produkce a percepce (Blommaert 2013; Szabó - Troyer 2017) a výhledově také mluvené slovo a haptické a olfaktorické vjemy, kterým se zatím moc pozornosti nedostalo. Místo antropologie ve studiu jazykové krajiny je opět zcela zásadní a otevírá se zde široké pole výzkumu. Jak transformujeme jazykové a kognitivní kategorie, toponyma či obecnější výpovědi o světě do performativních prvků typů cedulí, památníkủ či proslovů ve veřejném prostoru? Co můžeme $\mathrm{z}$ jazykové krajiny vyčíst o politice jazyka, sociálních vztazích a hierarchiích, skupinových identitách a politické ekonomii místa? Jak tyto performance ovlivňují naše vnímání a čtení krajiny - př́rodní, venkovské i té městské? 


\section{Jazyk, krajina a identita}

Již z Bassových prací bylo zřejmé, že intimní vztah, který si člověk utváří s krajinou, v níž žije, má jak individuální, tak kolektivní sdílený rozměr. Jméno osoby či místa totiž zakládá identitu (Helleland 2012; Woodman 2014). Ke krajině můžeme promlouvat individuálně, ale používáme $\mathrm{k}$ tomu sdílený jazykový kód, který charakterizuje určité společenství. Činíme tak zcela samozřejmě v každodenních situacích např́íklad tím, že užíváme různé referenční a toponymické systémy v závislosti na tom, zda mluvíme s místními či cizími (Gabbert 2007), respektive zda mluvíme s členy té či oné sociální skupiny (Krško 2013). Hranice mezi skupinami přitom může být vyjádřena mnoha různými způsoby. $\mathrm{V}$ př́ípadě textů $\mathrm{v}$ jazykové krajině to může být např́iklad volba určité varianty jména, použité písmo, umístění a pořadí jmen na cedulích, umístění a kontext cedule a doprovodná symbolika, $\mathrm{v}$ prípadě řečových aktů to může navíc být vedle toponymických variant také samotná výslovnost jmen, která jsou jinak sdílená (Kearns Berg 2002).

Specifickou roli v reprodukci skupinových identit hrají jazyk a jazyková krajina v multietnických a multilingvních společnostech. Menšinová toponyma a další texty ve veřejném prostoru mají pro př́slušníky menšin zvláštní význam - představují př́ležitost k revitalizaci menšinového jazyka a symbolické uznání jejich existence a domovského práva (Cenoz - Gorter 2006; Jordan 2009; Marten - Van Mensel - Gorter 2012). Proto také mohou vyvolávat odpor ze strany většinové společnosti, která v nich vidí ohrožení svého jazykového monopolu na krajinu (Puzey 2009). Vyjednávání o podobě jazykové krajiny například v souvislosti se zaváděním dvoja vícejazyčných nápisů a uličních názvů spolu s vlivem takových textů na percepci krajiny se tak stává velmi aktuálním tématem výzkumu (viz napr. Shohamy - Gorter 2009; Shohamy et al. 2010; Gorter - Marten - Van Mensel 2012; Azaryahu 2012; Puzey - Konstanski 2016; Rezaei - Tadayyon 2018; Mácha 2020).

Volbou jména, respektive jazykově-krajinného kódu zároveň vymezujeme hranice společenství a utvrzujeme se vzájemně v tom, že si sdílením stejného referenčního rámce a toponymického registru ontologicky i metafyzicky rozumíme a že jako skupina patř́me $\mathrm{k}$ dané krajině. Velmi patrné je to ve výše uvedeném př́ípadě dvoj- či vícejazyčných nápisů, kde se střetávají odlišné toponymické registry a krajinné představy. Platí to ovšem i pro monolingvní prostředí tam, kde jména nabývají skupinových asociací a kde se prostřednictvím jmen legitimizuje určitá představa společenství, typicky národního charakteru (Šakaja - Stanić 2011; Bucher et al. 2013; Drozdzewski 2014; Mácha et al. 2018). Dobrým př́kladem mohou také být 
dlouhodobé konflikty spojené s pojmenováváním ulic po Martinu Lutheru Kingovi na jihovýchodě USA (Alderman - Inwood 2013).

Podobně štěpícím jménem v českém kontextu je třeba Václav Havel, po němž vzhledem k silnému odporu části obyvatel nejsou pojmenovány téměř žádné významné ulice či náměstí. Zde tou štěpící linií ale není etnorasová př́slušnost jako v USA, nýbrž odlišná politická orientace jeho podporovatelů a odpůrců (viz např. Šverdík 2015; Horáková 2016). Jiným př́kladem identitárně motivované toponymické politiky z českého prostředí je odstranění německých jmen z krajiny bývalých Sudet. Statisíce místních a pomístních jmen z krajiny po vyhnání německy mluvícího obyvatelstva po druhé světové válce zcela a nenávratně zmizely. Snaha o degermanizaci dokonce zasáhla i jména, která s př́tomností německy hovořících obyvatel vůbec nesouvisela - viz přejmenování Německého Brodu na Havlíčkův Brod (David 2011: 121-127). Absence některých jmen v krajině je proto v tomto prípadě podobně významuplná jako prítomnost těch dochovaných (Woodman 2015).

Př́klad německých jmen v Sudetech upozorňuje na další a v rámci tohoto textu již poslední rozměr vztahu jazyka, krajiny a identity a tím je kulturně-historická hodnota zeměpisných jmen. S německými jmény, často velmi starými a nářečně unikátními, zmizela totiž také bohatá kulturní pamět a krajinné zkušenosti generací hospodářu a poutníků. Jen někde zůstala zachována dílčí toponymická kontinuita (viz např. Pleskalová 1986; Klemensová 2017; Lábus - Vrblík 2018). Jak proto navrhuje celá řada autorů, na zeměpisná jména bychom měli začít pohlížet jako na jednu z forem nehmotného kulturního dědictví. Toto dědictví má jak obecný význam jako dědictví celého lidstva, tak zvláštní význam jako dědictví konkrétních lokálních společenství (Jordan et al. 2009; David - Mácha 2014; Cantile - Kerfoot 2016; Škofic 2017).

V této partikulární rovině je toponymické kulturní dědictví krajiny úzce spjato $\mathrm{s}$ kolektivní identitou. Na řadě míst světa je toto dědictví mobilizováno na podporu emancipačních a dekolonizačních projektů různého charakteru (napr. Berg - Kearns 1996; Herman 1999; Nash 1999; Oliveira 2009). Kulturní dědictví je nutně politické, protože rozhodnutí o tom, co chránit a jak, je málokdy konsenzuální a vždy je někdo upřednostněn a jiný vyloučen. Otázka, čí dědictví by se mělo chránit, je nutně kontroverzní (Buciek - Baerenholdt - Juul 2006). Jak ukazuje př́klad německých jmen v české krajině, toponymické kulturní dědictví se obzvlášt nabízí jako př́íklad takzvaného disharmonického dědictví (dissonant heritage), o kterém psali Tunbridge a Ashworth (1996). Antropologie zde opět může přispět v rovině základního i aplikovaného výzkumu. Multivokalita, moc a konflikt $\mathrm{v}$ percepci a roli toponym $\mathrm{v}$ utváření představy o identitě společenství, jeho 
krajině a jeho kulturním dědictví jsou stále málo probádané (viz např. Alderman 2003; Fuchs 2015). V aplikované rovině může antropologie naopak nabídnout etnografické metody $\mathrm{k}$ záchraně, revitalizaci a pedagogickému využití mizejícího toponymického dědictví (viz např. Heikkilä - Fondahl 2010; Mark - Stea - Topaha 2019).

\section{Závěr}

V tomto textu jsem se pokusil poukázat na význam krajinné etnoekologie a roli jazyka v percepci a utváření krajiny a skupinových identit. Nelze než souhlasit s Yoonem (2017), že současná antropologie i geografie by hodně získaly systematickým studiem „lidové geografie“ (folk geography). Za prvé, lokální geografická znalost může pomoci rozš́řit a zpřesnit expertní znalost určitého území, což má př́mou vazbu na praxi (hospodaření s vodou, sesuvy, mikroklima, suroviny, eroze, výskyt organismů, ochrana př́rody atd.). A za druhé, studium lokální krajinné etnoekologie, jazykové krajiny a toponymické praxe může pomoci lépe pochopit vztah místních společenství $\mathrm{k}$ jejich prostředí, a to jak v rovině perceptuální, tak té behaviorální. Zatím je naše porozumění krajinné etnoekologii a roli jazyka v ní velmi útržkovité. Domnívám se, že tuto linii výzkumu bude nutné do budoucna výrazně a rychle rozvinout s ohledem na potřebu adaptace na klimatické změny, epidemie, migrace a další výzvy současného světa. A pozornost je třeba napřít především na naši vlastní společnost, protože o české etnoekologii toho mnohdy víme výrazně méně než o etnoekologii amazonských indiánů.

Kromě mnoha dílčích otázek a výzkumných námětů uvedených v jednotlivých kapitolách zbývá na závěr zmínit několik dalších, které procházejí např́ic kognicí, toponymií i identitou. Jedním z nich je např́íklad přenos fyzických jazykových krajin do krajin virtuálních. Navzdory potenciálně neomezeným možnostem internetu se vazba mezi fyzickými krajinami a krajinami virtuálními jeví jako relativně silná (Alderman 2009; Arthur - Williams 2019). Bez ohledu na to, kde se jazykové kategorie a toponymické strategie používají, je také nutné věnovat pozornost nově vznikajícím jménům a analyzovat mechanismy jejich vzniku, sdílení a zániku. Jména vždy byla velmi dynamickou složkou krajiny a ačkoliv paradigma kulturního dědictví a s ním spojená politika identit vyzdvihuje historická a etnická jména, paralelně vznikají tisíce nových jmen, o jejichž charakteru a socioprostorové dynamice toho víme velmi málo (Capra - Ganga 2019).

Jednou z dalších výzev budoucího studia jazyka a krajiny je využití map a technologií GIS při sběru, vizualizaci a vytváření popisu krajiny ve spo- 
lupráci se společenstvími, jichž se mapování týká. Takzvané participativní GIS (participatory GIS), GIS vedené společenstvím (community-driven GIS) či hluboké mapování (deep mapping) nabízejí nástroje k výzkumu i podpoře alternativních krajinných představ a potenciálně také $\mathrm{k}$ jejich ochraně jako jedné $\mathrm{z}$ forem kulturního dědictví. Vzhledem k zásadnímu významu GIS v současném zpracování dat ve společnosti je využívání GIS a participativního mapování v antropologii zatím stále v plenkách a přináší řadu závažných teoretických a metodologických otázek (viz např. Aporta 2005; Aswani - Lauer 2006; Hayman - Wedge - Colleen 2017; Wartmann - Purves 2017; Mark - Stea - Topaha 2019).

Možným tématem, kterým by se studium vztahu jazyka a krajiny mohlo dále zaobírat, je také způsob, jakým naši zkušenost krajiny verbalizujeme, tj. jak o krajině a místech v ní hovoříme (Enfield - San Roque 2017). Znalost gramatických pravidel a slovníků či vyčerpávajících soupisů toponym zaznamenaných etnografem $\mathrm{v}$ terénu a abstrahovaných od konkrétních společenství a mluvčích nemusí nutně odpovídat jazykové a toponymické kompetenci a každodenní praxi mluvčích určitého jazyka či obyvatel určité krajiny. Jak mé vlastní výzkumy ukázaly (Mácha 2014), toponymická znalost krajiny obyvatel Valašska není nijak velká a navíc výrazně kolísá v závislosti na věku, vztahu k místu, vzdělání, pohlaví, profesní orientaci a dalších faktorech. Toponymické registry různých sociálních skupin se překrývají jen částečně a toponymická improvizace je zcela běžná. Podobnou zkušenost udělali také např́íklad Tuck-Po (2016) či Reszegi (2020). Nalézt v terénu toponymické „mudrce“, na kterých postavil své práce Basso, je velmi obtížné. Z hlediska porozumění významu jazyka v percepci a utváření krajiny je navíc vlastně krajně nevhodné soustředit se při výzkumu na takové „mudrce“, nebot' nepředstavují typické mluvčí jazyka. Konfrontace gramatik, slovníků a soupisů s převažující žitou praxí je v dalším výzkumu absolutně nezbytná.

Problém souladu jazyka, krajinné percepce a krajinného chování je však ještě složitější. Jak ukázali třeba Feinberg a Genz (2012) na př́ikladu znalosti a schopnosti tradiční navigace v Polynésii, mezi znalostí krajiny demonstrovanou úspěšnou navigací mezi pacifickými ostrovy a slovním popisem této cesty navigátorem nemusí panovat nutně soulad, respektive ne všechny somatické znalosti potřebné k dobré navigaci (napřs. vycítění změn v mořských proudech a směrech větru) mají adekvátní jazykové vyjádření a ne všechny lingvistické kategorie (např. hvězdné kompasy, toponymie aj.) nacházejí analogii v somatických schopnostech. Jako další vhodný směr zkoumání vztahu jazyka a krajiny se proto nabízí výzkum souladu a překryvu mezi jazykovou a somatickou znalostí krajiny, respektive v jakých situacích je jazyková znalost významnější než ta somatická 
a naopak, jak se vzájemně podporují či omezují a jak pomocí studia obou z nich můžeme lépe porozumět našemu vztahování se ke světu a našemu prostorovému chování.

Červenec 2021

\section{Literatura}

Albert, Bruce - Le Tourneau, François-Michel. 2007. Ethnogeography and resource use among the Yanomami: toward a model of "reticular space". Current anthropology 48, 4: 584-592. https://doi.org/10.1086/519914

Alderman, Derek H. 2000. A Street fit for a king: Naming places and commemoration in the American South. The Professional Geographer 52, 4: $672-684$.

Alderman, Derek H. 2003. Street names and the scaling of memory: the politics of commemorating Martin Luther King, Jr. within the African American community. Area 35, 2: 163-173.

Alderman, Derek H. 2009. Virtual place-naming, internet domains, and the politics of misdirection: the case of www.martinlutherking.org. In: Berg, Lawrence D. - Vuolteenaho, Jani (eds.): Critical Toponymies: The Contested Politics of Place Naming. Farnham: Ashgate Publishing Ltd.: 267-283.

Alderman, Derek H. - Inwood, Joshua. 2013. Street naming and the politics of belonging: spatial injustices in the toponymic commemoration of Martin Luther King Jr. Social \& Cultural Geography 14, 2: 211-233. https://doi.org/10.1080/14649365.2012.754488

Aporta, Claudio. 2005. From map to horizon; from trail to journey: documenting Inuit geographic knowledge. Études/Inuit/Studies 29, 1-2: 221-231. https://doi.org/10.7202/013941ar

Aporta, Claudio. 2010. The Sea, the Land, the Coast, and the Winds: Understanding Inuit Sea Ice Use in Context. In: Krupnik, Igor Aporta, Claudio - Gearheard, Shari - Laidler, Gita J. - Kielsen Holm, Lene (eds.): SIKU: Knowing our ice. Mapping Inuit sea ice knowledge, use, and change in Nunavut, Canada (Cape Dorset, Igloolik, Pangnirtung). London - New York: Springer: 163-180.

Arthur, Rudy - Williams, Hywel T. P. 2019. The human geography of Twitter: quantifying regional identity and inter-region communication in England and Wales. PloS one 14, 4: e0214466. https://doi. org/10.1371/journal.pone.0214466 
Aswani, Shankar - Lauer, Matthew. 2006. Incorporating fishermen's local knowledge and behavior into geographical information systems (GIS) for designing marine protected areas in Oceania. Human Organization 65, 1: 81-102. https://doi.org/10.17730/ humo.65.1.4y2q0vhe4130n0uj

Azaryahu, Maoz. 2012. Hebrew, Arabic, English: the politics of multilingual street signs in Israeli cities. Social \& Cultural Geography 13, 5: 461-479. https://doi.org/10.1080/14649365.2012.698748

Azaryahu, Maoz - Golan, Arnon. 2001. (Re)naming the landscape: the formation of the Hebrew map of Israel 1949-1960. Fournal of Historical Geography 27, 2: 178-195. https://doi.org/10.1006/jhge.2001.0297

Basso, Keith A. 1988. Speaking with names: language and landscape among the Western Apache. Cultural Anthropology 3, 2: 99-130. https:// doi.org/10.1525/can.1988.3.2.02a00010

Basso, Keith A. 1996. Wisdom sits in places. Landscape and language among the Western Apache. Albuquerque: University of New Mexico Press.

Berg, Lawrence D. - Kearns, Robin A. 1996. Naming as norming: 'race', gender, and the identity politics of naming places in Aotearoa/New Zealand. Environment and Planning D: Society and Space 14, 1: 99-122. https://doi.org/10.1068/d140099

Bigon, Liora. 2016. Place names in Africa. Colonial urban legacies, entangled histories. Springer International Publishing.

Blaut, Jim M. 1979. Some Principles of Ethnogeography. In: Gale, Stephen - Olsson, Gale (eds.): Philosophy in Geography. Dordrecht Boston - London: D. Reidel Publishing Company: 1-8.

Blommaert, Jan. 2013. Ethnography, superdiversity and linguistic landscapes: chronicles of complexity. Bristol - Buffalo - Toronto: Multilingual Matters.

Boas, Franz. 1934. Geographical Names of the Kwakiutl Indians. New York: Columbia University Press.

Boden, Gertrud. 2011. The documentation of place names in an endangered language environment: a case study of the !Xoon in southern Omaheke, Namibia. Anthropological Linguistics 53, 1: 34-76.

Bright, William. 2003. What is a name? Reflections on onomastics. Language and Linguistics 4, 4: 669-681.

Brown, Penelope. 2008. Up, down, and across the land: landscape terms, place names, and spatial language in Tzeltal. Language Sciences 30, 2-3: 151-181. https://doi.org/10.1016/j.langsci.2006.12.003

Bucher, Slavomír et al. 2013. The perception of identity through urban toponyms in the regional cities of Slovakia. Anthropological Notebooks 19, 3: $23-40$. 
Buciek, Keld - Baerenholdt, Jørgen Ole - Juul, Kristine. 2006. Whose heritage? Immigration and place narratives in Denmark. Geografiska Annaler: Series B, Human Geography 88, 2: 185-197. https://doi. org/10.1111/j.0435-3684.2006.00214.x

Burenhult, Niclas - Levinson, Stephen C. 2008. Language and landscape: a cross-linguistic perspective. Language Sciences 30, 2-3: 135-150. https://doi.org/10.1016/j.langsci.2006.12.028

Cablitz, Gabriele H. 2008. When "what" is "where": a linguistic analysis of landscape terms, place names and body part terms in Marquesan (Oceanic, French Polynesia). Language Sciences 30, 2-3: 200-226. https://doi.org/10.1016/j.langsci.2006.12.004

Cantile, A. - Kerfoot, H. (eds.). 2016. Place names as intangible cultural heritage. Firenze: IGMI.

Capra, Gian Franco - Ganga, Antonio. 2019. The intangible heritage of the anthropocene: the toponymic revolution in the human age. Names 67, 3: 125-135. https://doi.org/10.1080/00277738.2018.1452887

Cenoz, Jasone - Gorter, Durk. 2006. Linguistic Landscape and Minority Languages. International fournal of Multilingualism 3, 1: 67-80. https:// doi.org/10.1080/14790710608668386

Clifford, James - Marcus, George E. (eds.). 1986. Writing culture: the poetics and politics of ethnography. Berkeley: University of California Press.

Cogos, Sarah - Roué, Marie - Roturier, Samuel. 2017. Sami place names and maps: transmitting knowledge of a cultural landscape in contemporary contexts. Arctic, Antarctic, and Alpine Research 49, 1: 43-51. https://doi.org/10.1657/AAAR0016-042

Cohen, Saul B. - Kliot, Nurit. 1992. Place-names in Israel's ideological struggle over the administered territories. Annals of the Association of American Geographers 82, 4: 653-680.

Cosgrove, Denis E. 1998. Social formation and symbolic landscape. Madison: University of Wisconsin Press.

Cruikshank, Julie. 1990. Getting the words right: perspectives on naming and places in Athapaskan oral history. Arctic Anthropology 27, 1: $52-65$.

David, Jaroslav. 2011. Smrdov, Brežněves a Rychlonožkova ulice: kapitoly z moderní české toponymie; mistní jména, uliční názoy, literární toponyma. Praha: Academia.

David, Jaroslav - Mácha, Přemysl. 2014. Názvy míst - pamèt', identita, kulturní dědictuí. Brno: Host.

Descartes, René. 1992. Rozprava o metodè. Praha: Nakladatelství Svoboda. 
Descola, Philippe. 1994. In the society of nature: a native ecology in Amazonia. Cambridge: Cambridge University Press.

Descola, Philippe. 2013. Beyond nature and culture. Chiacago: University of Chicago Press.

Drozdzewski, Danielle. 2014. Using history in the streetscape to affirm geopolitics of memory. Political Geography 42, 66-78. https://doi. org/10.1016/j.polgeo.2014.06.004

Duranti, Alessandro et al. 2003. Language as culture in US anthropology: Three paradigms. Current anthropology 44, 3: 323-347. https://doi.org/10.1086/368118

Enfield, Nicholas J. - San Roque, Lila. 2017. Place reference in interaction. Open Linguistics 3, 1: 582-590. https://doi.org/10.1515/opli2017-0029

Feinberg, Richard - Genz, Joseph. 2012. Limitations of language for conveying navigational knowledge: way-finding in the Southeastern Solomon Islands. American Anthropologist 114, 2: 336-350. https://doi. org/10.1111/j.1548-1433.2012.01429.x

Friederici, Angela D. 2017. Language in our brain: the origins of a uniquely human capacity. Cambridge: MIT Press.

Fuchs, Stephan. 2015. History and heritage of two Midwestern towns: a toponymic-material approach. Fournal of Historical Geography 48: 11-25. https://doi.org/10.1016/j.jhg.2015.01.003

Gabbert, Lisa. 2007. Distanciation and the recontextualization of space: Finding one's way in a small western community. Fournal of American Folklore 120, 476: 178-203.

Gibas, Petr - Pauknerová, Karolína. 2009. Mezi pravěkem a industriálem: několik poznámek k antropologii krajiny. Český lid 96, 2: 131-146.

Gill, Graeme. 2005. Changing symbols: the renovation of Moscow place names. The Russian Review 64, 3: 480-503.

González Faraco, J. Carlos - Murphy, Michael D. 1997. Street names and political regimes in an Andalusian town. Ethnology 36, 2: 123-148.

Goodenough, Ward H. - Thomas, Stephen D. 1987. Traditional navigation in the Western Pacific. Expedition 19, 3: 2-14.

Gorter, Durk - Marten, Heiko F. - Van Mensel, Luk (eds.). 2012. Minority languages in the linguistic landscape. New York: Palgrave MacMillan.

Grenoble, Lenore A. - McMahan, Hilary - Kleist Petrussen, Alliaq. 2019. An ontology of landscape and seascape in Greenland: the linguistic encoding of land in Kalaallisut. International fournal of American Linguistics 85, 1: 1-43. https://doi.org/10.1086/700317 
Hansen, Magnus P. - O’Meara, Carolyn. 2020. Environmental adaptation in language: spatial grammar, landscape knowledge and human survival. Language Dynamics and Change 10, 2: 230-258. https://doi.org/10.1163/22105832-bja10002

Harrington, John P. 1916. The ethnogeography of the Tewa Indians. Washington: US Government Printing Office.

Harrington, John P. 1920. Old Indian Geographical Names around Santa Fe, New Mexico. American Anthropologist 22, 4: 341-359.

Haun, Daniel B. M. - Rapold, Christian J. - Janzen, Gabriele Levinson, Stephen C. 2011. Plasticity of human spatial cognition: spatial language and cognition covary across cultures. Cognition 119, 1: 70-80. https://doi.org/10.1016/j.cognition.2010.12.009

Hayman, Eleanor - Wedge, Mark - Colleen, James. 2017. A deep chart (the aqua-face of deep mapping) collaborative water research with Carcross/Tagish First Nation, Shaanakhéeni headwaters, Yukon Territory/British Columbia, Canada. International Fournal of Humanities and Arts Computing 11, 1: 86-108. https://doi.org/10.3366/ ijhac.2017.0180

Heegård, Jan - Liljegren, Henrik. 2018. Geomorphic coding in Palula and Kalasha. Acta Linguistica Hafniensia 50, 2: 129-160. https://doi.org /10.1080/03740463.2018.1432210

Heikkilä, Karen. 2014. The forest is our inheritance: an introduction to Semai Orang Asli place-naming and belonging in the Bukit Tapah Forest Reserve. Singapore Fournal of Tropical Geography 35, 3: 362-381. https://doi.org/10.1111/sjtg.12073

Heikkilä, Karen - Fondahl, Gail. 2010. Indigenous toponyms as pedagogical tools: reflections from research with Tl'azt'en Nation, British Columbia. Fennia-International fournal of Geography 188, 1: 105-122.

Helleland, Botolv. 2012. Place names and identities. Oslo Studies in Language 4, 2: 95-116. https://doi.org/10.5617/osla.313

Herman, R. D. K. 1999. The Aloha state: place names and the anti-conquest of Hawai'i. Annals of the Association of American Geographers 89, 1: 76-102.

Hirsch, Eric - O'Hanlon, Michael (eds.). 1995. The Anthropology of Landscape: Perspectives on Space and Place. Oxford: Oxford University Press.

Holub, Josef - Lyer, Stanislav. 1967. Stručný etymologický slowník jazyka českého. Praha: Státní pedagogické nakladatelství.

Horáková, Veronika. 2016. Do uličky Václava Havle zase připsali Klause. Výrokem: A vy jste kdo? iDnes.cz [online]. 22. 3. 2016. [2021-05-21] 
Dostupné na: https://www.idnes.cz/brno/zpravy/v-ulicce-vaclavahavla-pribyl-klausuv-vyrok.A160322_135750_brno-zpravy_vh.

Horsman, Stuart. 2006. The politics of toponyms in the Pamir mountains. Area 38, 3: 279-291. https://doi.org/10.1111/j.14754762.2006.00697.x

Hunn, Eugene. 1996. Columbia Plateau Indian place names: what can they teach us? Fournal of Linguistic Anthropology 6, 1: 3-26.

Ingold, Tim. 2000. The perception of the environment: essays on livelihood, dwelling and skill. London - New York: Routledge.

Ingold, Tim. 2011. Being alive: essays on movement, knowledge and description. London - New York: Routledge.

Jackson, John B. 1984. Discovering the Vernacular Landscape. New Haven: Yale University Press.

Jett, Stephen C. 1997. Place-naming, environment, and perception among the Canyon de Chelly Navajo of Arizona. Professional Geographer 49, 4: 481-493.

Johnson, Leslie M. - Hunn, Eugene S. (eds.). 2010a. Landscape ethnoecology: concepts of biotic and physical space. New York - Oxford: Berghahn Books.

Johnson, Leslie M. - Hunn, Eugene S. 2010b. Introduction. In: Johnson, Leslie M. - Hunn, Eugene S. (eds.): Landscape ethnoecology: concepts of biotic and physical space. New York - Oxford: Berghahn Books: 1-14.

Jordan, Peter. 2009. Place names as ingredients of space-related identity. In: Jordan, Peter - Bergmann, Hubert - Cheetham, Catherine Hausner, Isolde (eds.): Geographical Names as a Part of the Cultural Heritage. Wien: Institut für Geographie und Regionalforschung der Universität Wien: 33-39.

Jordan, Peter - Bergmann, Hubert - Cheetham, Catherine - Hausner, Isolde (eds.). 2009. Geographical Names as a Part of the Cultural Heritage. Wien: Institut für Geographie und Regionalforschung der Universität Wien.

Jungmann, Josef. 1836. Slownjk česko-německý. Djl II. K-O. Praha.

Kapusta, Jan. 2015. Mayské křriže, hory a jeskyně ve světle ontologického relativismu a fenomenologické antropologie. Český lid 102, 4: 437-463.

Kearns, Robin A. - Berg, Lawrence D. 2002. Proclaiming Place: Towards a Geography of Place Name Pronunciation. Social and Cultural Geography 3, 3: 283-302. https://doi. org/10.1080/1464936022000003532

Kingston, Deanna Paniataaq. 2009. Almost every place, every rock, had a name: a consideration of place-name density on King Island, 
Alaska. AlterNative: An International fournal of Indigenous Peoples 5, 1: 6-25. https://doi.org/10.1177/117718010900500102

Klemensová, Tereza. 2017. V Gruntě a Špicberk - toponyma německého původu v pohraničí v současnosti (na př́kladu vybraných obcí Jesenicka). Naše řeč 100, 5: 301-311.

Koch, Harold - Hercus, Luise (eds.). 2009. Aboriginal placenames: naming and re-naming the Australian landscape. Acton: Australian National University Press.

Krško, Jaromír. 2013. Toponymický priestor ako súčast' kultúrnoantropologického priestoru. Acta onomastica 54: 151-169.

Kř́žová, Lenka et al. (eds.). 2017. Od Karlova mostu ke Gottwaldovu. Osobnosti v názvech měst a mist. Praha: Historický ústav.

Landy, Rodrigue - Bourhis, Richard Y. 1997. Linguistic landscape and ethnolinguistic vitality: an empirical study. Fournal of Language and Social Psychology 16, 1: 23-49. https://doi. org/10.1177/0261927X970161002

Lábus, Václav - Vrblík, Daniel. 2018. Toponyma v krajině a možnosti jejich výzkumu. Liberec: Technická univerzita v Liberci.

Laidler, Percy W. 1927. The place-names of the Nama Hottentots, gathered in the Richtersveld and Kamiesberg Districts of Little Namaqualand. Man 27: 147-150.

Levinson, Stephen C. 1996. Language and space. Annual Review of Anthropology 25, 1: 353-382. https://doi.org/10.1146/annurev. anthro.25.1.353

Levinson, Stephen C. 2003. Space in language and cognition: Explorations in cognitive diversity. Cambridge: Cambridge University Press.

Levinson, Stephen C. 2008. Landscape, seascape and the ontology of places on Rossel Island, Papua New Guinea. Language Sciences 30, 2-3: 256-290. https://doi.org/10.1016/j.langsci.2006.12.032

Light, Duncan. 2004. Street names in Bucharest, 1990-1997: exploring the modern historical geographies of post-socialist change. Fournal of Historical Geography 30, 1: 154-172. https://doi.org/10.1016/S03057488(02)00102-0

Lucy, John A. 1997. Linguistic relativity. Annual Review of Anthropology 26, 1: 291-312. https://doi.org/10.1146/annurev.anthro.26.1.291

Mácha, Přemysl. 2010. Krajiny antropologie a antropologie krajiny. Český lid 97, 3: 225-246.

Mácha, Přemysl. 2014. Proměny toponymie a krajiny na př́íkladu Velkých Karlovic, Karolinky a Nového Hrozenkova. In: Urbanová, Svatava et al. (ed.): Valašsko. Historie a kultura. Ostrava: Ostravská univerzita v Ostravě: 429-442. 
Mácha, Přemysl. 2020. Dvojjazyčné nápisy na Těšínsku aneb těšínský venkov jako experiment s pluralitou. Národopisná revue 30, 3: 191-201.

Mácha, Přemysl - Krtička, Luděk. 2016. Exonyms as Metaphoric Endonyms: World History and Geography in Local Landscapes. In: Jordan, Peter - Woodman, Paul (eds.): Criteria for the Use of Exonyms. Proceedings of the 17th UNGEGN Working Group on Exonyms Meeting, Zagreb, 14-16 May 2015. Hamburg: Dr. Kovač Verlag: 99-114.

Mácha, Přemysl - Krtička, Luděk - Lassak, Horst. 2018. City divided: place names and nationalism in the Czech-Polish borderlands. Mitteilungen der Österreichischer Geographischer Gesellschaft 160: 303-329. https://doi.org/10.1553/moegg160s303 Majid, Asifa - Bowerman, Melissa - Kita, Sotaro - Haun, Daniel B.M. Levinson, Stephen C. 2004. Can language restructure cognition? The case for space. Trends in Cognitive Sciences 8, 3: 108-114. https://doi. org/10.1016/j.tics.2004.01.003

Mark, David M. - Turk, Andrew D. - Stea, David. 2010. Ethnophysiography of arid lands. In: Johnson, Leslie M. - Hunn, Eugene S. (eds.): Landscape ethnoecology: concepts of biotic and physical space. New York - Oxford: Berghahn Books: 27-48.

Mark, David M. - Turk, Andrew G. - Burenhult, Niclas - Stea, David (eds.). 2011. Landscape in language: transdisciplinary perspectives. Amsterdam - Philadelphia: John Benjamins Publishing Company.

Mark, David M. - Stea, David - Topaha, Carmelita. 2019. An illustrated dictionary of Navajo landscape terms. Bern: Peter Lang Publishing.

Marten, Heiko F. - Van Mensel, Luk - Gorter, Durk. 2012. Studying minority languages in the linguistic landscape. In: Gorter, Durk Marten, Heiko F. - Van Mensel, Luk (eds.): Minority languages in the linguistic landscape. New York: Palgrave MacMillan, 1-15.

McCarthy, Helen. 1986. Salt Pomo: an ethnogeography. Fournal of California and Great Basin Anthropology 8, 1: 24-36.

Meadows, William C. 2008. Kiowa ethnogeography. Austin: University of Texas Press.

Mirkowich, Nicholas. 1941. A note on Navajo place names. American Anthropologist 43, 2: 313-314.

Nash, Catherine. 1999. Irish placenames: post-colonial locations. Transactions of the Institute of British Geographers 24, 4: 457-480. https:// doi.org/10.1111/j.0020-2754.1999.00457.x

Nash, Joshua et al. 2020. On languages on islands. Acta Linguistica Hafniensia 52, 1: 81-116. https://doi.org/10.1080/03740463.2020.1736747

O'Connor, Loretta - Kroefges, Peter C. 2008. The land remembers: landscape terms and place names in Lowland Chontal of Oaxaca, 
Mexico. Language Sciences 30, 2-3: 291-315. https://doi.org/10.1016/j. langsci.2006.12.007

Oliveira, Katrina-Ann R. 2009. Wahi a kahiko: place names as vehicles of ancestral memory. AlterNative: An International fournal of Indigenous Peoples 5, 2: 101-115. https://doi.org/10.1177/117718010900500206

Olwig, Kenneth. 1996. Recovering the substantive nature of landscape. Annals of the American Association of Geographers 86, 4: 630-653.

O'Meara, Carolyn - Burenhult, Niclas - Rothstein, Mikael - Sercombe, Peter. 2020. Representing space and place: hunter-gatherer perspectives. Hunter Gatherer Research 4, 3: 287-309. https://doi. org/10.3828/hgr.2018.19

Pauknerová, Karolína. 2019. Krajina mezi pamètí a zapomínáním. Praha: Karolinum.

Palonen, Emilia. 2008. The city-text in post-communist Budapest: street names, memorials, and the politics of commemoration. Geofournal 73, 3: 219-230.

Pleskalová, Jana. 1986. Zur Entwicklung der früheren deutschen Mikrotoponymie in tschechischer Umgebung. Onomastica Slavogermanica 15: 157-161.

Puzey, Guy. 2009. Opportunity or Threat? The Role of Minority Toponyms in the Linguistic Landscape. In: Ahrens, Wolfgang et al. (eds.): Names in multi-lingual, multi-cultural and multi-ethnic contact. Proceedings of the 23rd International Congress of Onomastic Sciences August 17-22, 2008, York University, Toronto, Canada. Toronto: York University: 821-827.

Puzey, Guy - Konstanski, Laura. 2016. Names and naming: people, places, perceptions and power. Bristol - Buffalo - Toronto: Multilingual Matters.

Radding, Lisa - Western, John. 2010. What's in a name? Linguistics, geography, and toponyms. Geographical Review 100, 3: 394-412. https://doi.org/10.1111/j.1931-0846.2010.00043.x

Reszegi, Katalin. 2020. Toponyms and spatial representations. Onomastica 64: 23-39. https://doi.org/10.17651/ ONOMAST.64.4

Rezaei, Saeed - Tadayyon, Maedeh. 2018. Linguistic landscape in the city of Isfahan in Iran: The representation of languages and identities in Julfa. Multilingua 37, 6: 701-720.

Rose-Redwood, Reuben. 2008. Sixth Avenue is now a memory: regimes of spatial inscription and the performative limits of the official citytext. Political Geography 27, 8: 875-894. https://doi.org/10.1016/j. polgeo.2008.11.002 
Rose-Redwood, Reuben - Alderman, Derek H. - Azaryahu, Maoz. 2010. Geographies of toponymic inscription: new directions in critical placename studies. Progress in Human Geography 34, 4: 453-470. https://doi. org/10.1177/0309132509351042

Scollon, Ron - Scollon, Suzie Wong. 2003. Discourses in place. Language in the material world. London - New York: Routledge.

Sharifian, Farzad. 2017. Cultural linguistics and linguistic relativity. Language Sciences 59: 83-92. https://doi.org/10.1016/j. langsci.2016.06.002

Shohamy, Elana - Gorter, Durk (eds.). 2009. Linguistic landscape. Expanding the scenery. London, New York: Routledge.

Shohamy, Elana - Ben-Rafael, Eliezer - Barni, Monica (eds.). 2010. Linguistic landscape in the city. Bristol - Buffalo - Toronto: Multilingual Matters.

Shoval, Noam. 2013. Street-naming, tourism development and cultural conflict: the case of the Old City of Acre/Akko/Akka. Transactions of the Institute of British Geographers 38, 4: 612-626. https://doi. org/10.1111/tran.12003

Smith, Barry - Mark, David M. 2003. Do mountains exist? Towards an ontology of landforms. Environment and Planning B: Planning and Design 30, 3: 411-427. https://doi.org/10.1068/b12821

Sturtevant, William C. 1964. Studies in Ethnoscience. American Anthropologist 66, 3: 99-131.

Szabó, Tamás Péter - Troyer, Robert A. 2017. Inclusive ethnographies: beyond the binaries of observer and observed in linguistic landscape studies. Linguistic Landscape 3, 3: 306-326. https://doi.org/10.1075/ 1l.17008.sza

Šakaja, Laura - Stanić, Jelena. 2011. Other (ing), self (portraying), negotiating: the spatial codification of values in Zagreb's citytext. Cultural geographies 18, 4: 495-516.

Škofic, Jožica. 2017. Microtoponyms as an important part of Slovenian cultural heritage. Acta Geographica Slovenica 57, 1: 141-152. https://doi. org/10.3986/AGS.4670

Šverdík, Michal. 2015. Pojmenujte ulici či náměstí po Václavu Havlovi, žádá petice. iDnes.cz [online]. 24. 6. 2015 [2021-05-21]. Dostupné z: https://www.idnes.cz/olomouc/zpravy/petice-za-pojmenovaninamesti-po-vaclavu-havlovi-prostejov.A150622_2172122_olomouczpravy_stk.

Thornton, Thomas. 1997. Know your place: the organization of Tlingit geographic knowledge. Ethnology 36, 4:295-307. https://doi. org/10.2307/3774039 
Thornton, Thomas. 2011. Being and Place among the Tlingit. Seattle: University of Washington Press.

Tilley, Christopher. 1994. A phenomenology of landscape: places, paths, and monuments. Oxford: Berg.

Tuan, Yi-Fu. 1991. Language and the making of place: a narrativedescriptive approach. Annals of the Association of American Geographers 81, 4: 684-696.

Tuck-Po, Lye. 2016. Signaling presence. How Batek and Penan huntergatherers in Malaysia mark the landscape. In: Lovis, William Whallon, Robert (eds.): Marking the land: hunter-gatherer creation of meaning in their environment. New York: Routledge: 231-260.

Tunbridge, John E. - Ashworth, Gregory J. 1996. Dissonant heritage: the management of the past as a resource in conflict. New York: Wiley.

Urban, Matthias. 2020. Mountain linguistics. Language and Linguistics Compass 14, 9: e12393. https://doi.org/10.1111/lnc3.12393

Van Maanen, John. 2011. Tales of the field: On writing ethnography. Chicago: University of Chicago Press.

Van Putten, Saskia et al. 2020. Conceptualisations of landscape differ across European languages. Plos one 15, 10: e0239858. https://doi. org/10.1371/journal.pone.0239858

Viveiros de Castro, Eduardo. 1998. Cosmological deixis and Amerindian perspectivism. Fournal of the Royal Anthropological Institute 4, 3: 469488.

Wartmann, Flurina M. - Purves, Ross S. 2017. What's (not) on the map: landscape features from participatory sketch mapping differ from local categories used in language. Land 6, 79: 1-16. https://doi. org/10.3390/land6040079

Weber, Brigitte (ed.). 2019. The linguistic heritage of colonial practice. Berlin - Boston: Walter de Gruyter.

Widlok, Thomas. 2008. Landscape unbounded: space, place, and orientation in $\neq$ Akhoe Hai//om and beyond. Language Sciences 30 , 2-3: 362-380.

Woodman, Paul. 2014. The interconnections between toponymy and identity. Review of Historical Geography and Toponomastics 9, 17-18: 7-20.

Woodman, Paul. 2015. The toponymy of absence. Review of Historical Geography and Toponomastics 10, 19-20: 7-16.

Wylie, John. 2005. A Single Day's Walking. Narrating Self and Landscape on the South West Coast Path. Transactions of the Institute of British Geographers 30, 2: 234-247. https://doi.org/10.1111/j.1475-5661.2005.00163.x 
Yeoh, Brenda S. A 1996. Street-naming and nation-building: toponymic inscriptions of nationhood in Singapore. Area 28, 3: 298-307.

Yoon, Hong-Key. 2017. Indigenous "Folk" Geographical Ideas and Knowledge. Advances in Anthropology 7, 4: 340-355. https://doi. org/10.4236/aa.2017.74020 